\title{
Flash Flood Modeling Using HEC-RAS (2D) model on Wadi Reem in the western region, Kingdom of Saudi Arabia
}

\author{
Mahmoud Abdelshafy ${ }^{1}$ and Alaa Mostafa ${ }^{2}$ \\ 1- Egyptian Environmental Affairs Agency (EEAA) \\ Email: che mma85@yahoo.com \\ 2- Geology Department, Faculty of Science, Assiut Branch, Al-Azhar University, Egypt \\ Email: alaamos@hotmail.com
}

Received March 26, 2021

Accepted: May 20, 2021

\begin{abstract}
Various infrastructures in Saudi Arabia are affecting by floods and rainfall that may damage constructions at urban areas due to water flows in the main valleys and streams. Asser Region in western Saudi Arabia is characterized by its high rainfall intensity that leads to flash floods. The present study aims to evaluate and identify potential floods in coastal areas of Wadi Reem basin and to show the urban areas exposed to flooding with flood water in the coastal city. Runoff calculation is an important part of regional runoff forecast and water resources evaluation model. The Soil Conservation Service (SCS) curve number $(\mathrm{CN})$ model developed by the U.S. Department of Agriculture National Resources Conversion Service (NRCS) is the most popular and widely applied model for direct runoff estimation. The current work used HEC-RAS (2D) in order to simulate Flood map depth and velocity in Wadi Reem coastal areas. Watershed and its stream was delineated using digital elevation model (DEM) and morphological parameters calculated using Watershed Modeling System (WMS). Rainfall frequency analysis was performed for selected three rainfall gages using annual maximums of 24-h rainfall. This study deals with geographic information systems (GIS), hydrologic modeling (water modeling system, WMS), and hydraulic modeling (Hydrologic Engineering Center River Analysis System, HECRAS) to evaluate the impact of flash flood hazards on Wadi Reem coastal area.
\end{abstract}

Keywords: Flash flood, Wadi Reem, Morphological parameters, HEC-HMS Modeling and HEC-RAS 2D Model.

\section{INTRODUCTION}

Flooding is common natural disaster with a devastating and widespread effect responsible for economic losses and mortality (Teng et al., 2017). Flood causes about third of all natural disasters in the world. Geographic Information Systems (GIS) and digital elevation models (DEM) are now commonly used for flood analysis and flood risk prediction. Floods are considered as one of the most common disasters and probably the most devastating (Baoyin and Hailin, 2009). Between 1998 and 2017, floods affected more than two billion people worldwide and flood together with storms and droughts contributed to $80-90 \%$ of the worldwide natural disasters in the last ten years (WHO, 2020).

The western region of Saudi Arabia is characterized by low altitude-flat coastal plain bounded from the east with a chain of high rugged mountains of the Arabian Shield oriented North-Northwest to South-Southeast. Many of the major cities and villages along the coastal 


\section{Mahmoud Abdelshafy and Alaa Mostafa}

plain are situated along or at the mouth of these wadis. Due to the aridity of the area and lack of long-term strategic planning, most of the population tends to settle along wadi courses and sides. Flash floods along these wadis caused severe damages to lives and properties in the past (Subyani et al., 2009).

Most parts of Saudi Arabia are classified as hot and dry (Köppen, 1936), where rainfall is irregular and the climate is characterized by high temperatures (Al-Jerash, 1985; Al-Taher, 1994). However, the south-western region of the country is classified as semi-arid (Köppen, 1936).This region is characterized by having rainfall throughout the year, where the topography enhances local convective rain (Al-Mazroui, 1998; Abdullah and Al-Mazroui, 1998).

The main objective of this study is to estimate the direct runoff of wadi Reem watershed and to generate Flood map depth and velocity using HEC-RAS 2D Model.

\section{METHODOLOGY AND DATA}

Methodology and Data used in this work as shown in Figure (1).

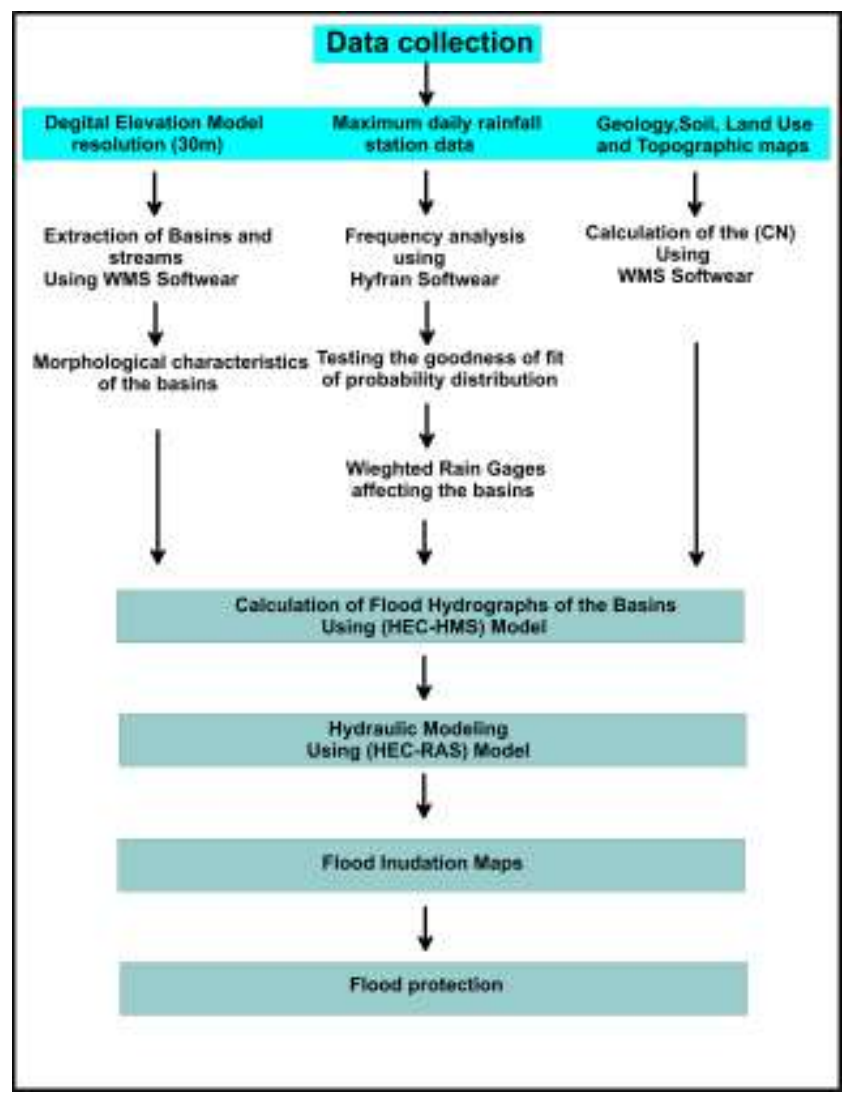

Fig. 1:Flowchart showing the methodology adopted in the current work.

\section{WMS model}

The study of morphometric basin characteristics in western Saudi Arabia is based on the DEM data. All the drainage basins and networks as well as their morphometric characteristics were extracted using the watershed modeling system (WMS, V.10.1) through the drainage module by selecting "Compute Basins Data", where the morphological properties of the basins were calculated automatically. These properties can be shown in the "Display option". This system provided most of the morphometric parameters of the studied basins and their stream 
Flash Flood Modeling Using HEC-RAS (2D) model on Wadi Reem in the western region, Kingdom of Saudi Arabia

attributes with the assumption that the flow accumulation threshold is 0.2 (Strahler 1952; Ally et al., 1980).

\section{Hydrologic Modeling}

In this study HEC-HMS Model was selected for the run off forecasting which play a key role in early flood warning. Program was developed by the US Army Corps of Engineers Hydrologic Engineering Center (HEC) and is the replacement for HEC-1 (Feldman, 1995).

\section{Hydraulic Modeling}

The hydraulic modeling software, Hydraulic Engineering Center-River Analysis System (HEC-RAS 5.0.4) is widely used open source hydraulic flow analysis programmer developed by the United States Army Corps of Engineers-Hydrologic Engineering Center (Hydrologic Engineering Centre, 2008, 2016). The model is available for 1D and 2D modeling. In this study a 2D HEC-RAS model was used.

\section{Study area and Location}

\section{RESULTS AND DISCUSSION}

The Wadi Reem catchment area is located in Asseer Region, Saudi Arabia, between latitudes $17^{\circ} 42^{\prime} 15.51^{\prime \prime} \mathrm{N}$ to $18^{\circ} 16^{\prime} 20.05^{\prime \prime} \mathrm{N}$ (North) and longitudes $41^{\circ} 59^{\prime} 35.68^{\prime \prime} \mathrm{E}$ to $42^{\circ} 22 ' 35.04 " \mathrm{E}$ (East) (Fig. 2).

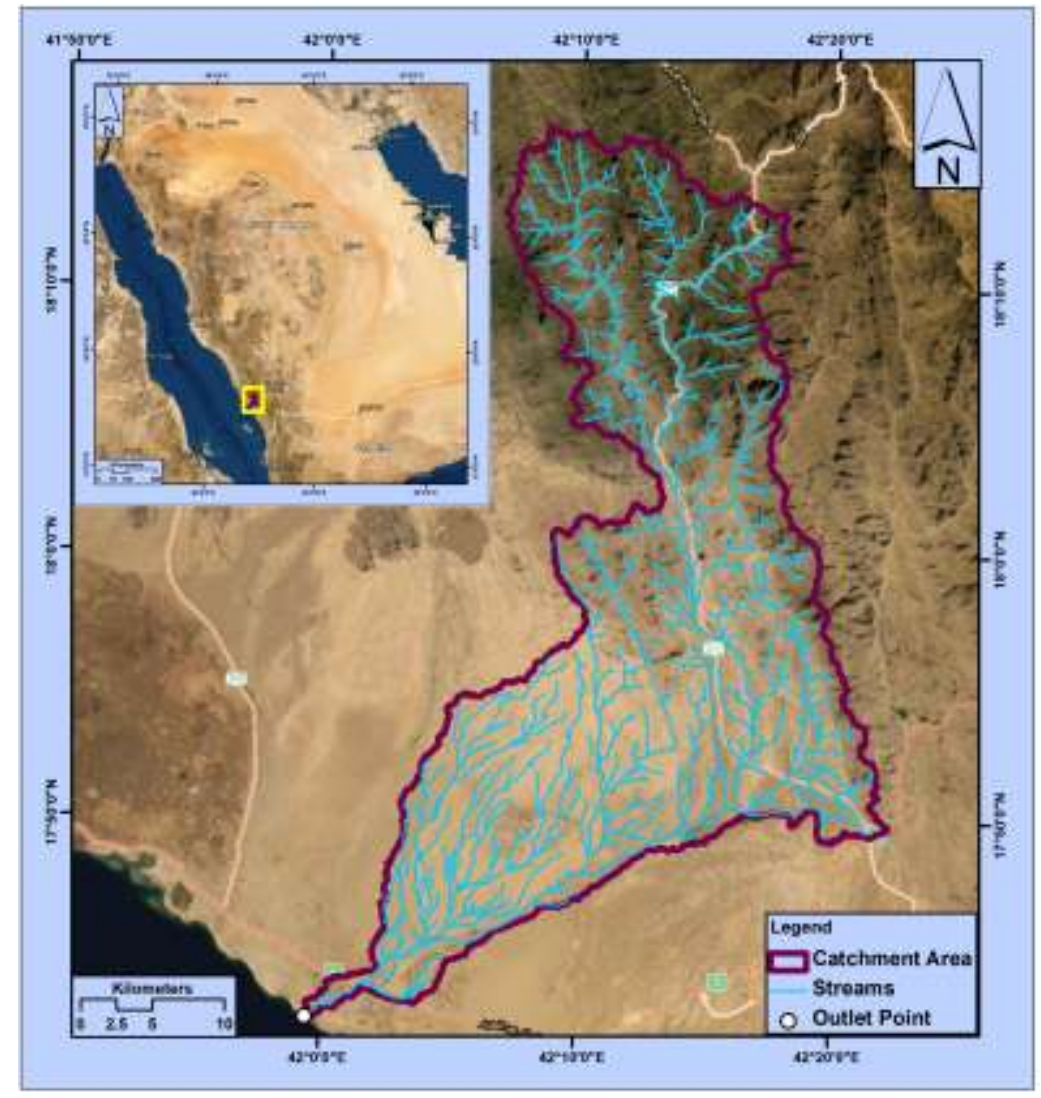

Fig. 2: Location Map of Wadi Reem basin. 


\section{Mahmoud Abdelshafy and Alaa Mostafa}

The study area basin is surrounded by high mountains from east and the north. Reem basin can be divided into three main topographic features; The Red Sea coastal plain (Tihamah), the Hills, and the Scarp of Hijaz Mountains. Tihamah area is a flatted land located in the East and North East of wadi Reem basin, and its width is about $33 \mathrm{~km}$ and its elevation varies from 0 level to $300 \mathrm{~m}$ above sea level. The hills are area which sloping slightly at west of the Scarp Mountains and the elevation of the hills varies from $400 \mathrm{~m}$ to 1,139 m above sea level (Fig. 3).

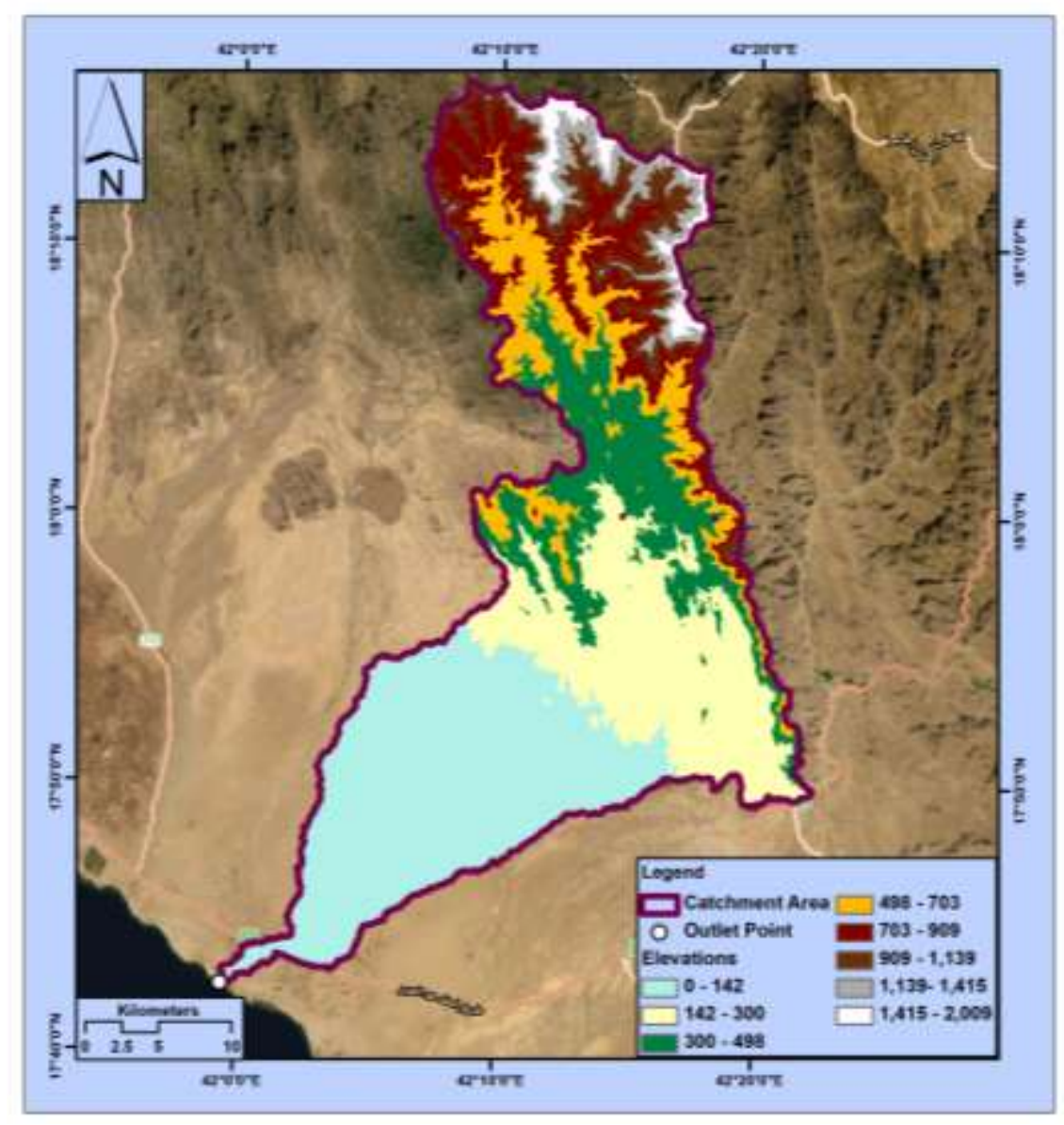

Fig. 3: Digital elevation map (DEM) of Wadi Reem basin.

\section{Morphological characteristics}

Basic parameters such as area, perimeter, elevation, slope, width, length of watershed and stream length could be extracted directly from the DEM using WMS Softwear. The Wadi Reem drainage basin has an area $205.42 \mathrm{~km}^{2}$ and the main morphological parameters of Wadi Reem basin are shown in Figure (4) and Table (1). 
Flash Flood Modeling Using HEC-RAS (2D) model on Wadi Reem in the western region, Kingdom of Saudi Arabia

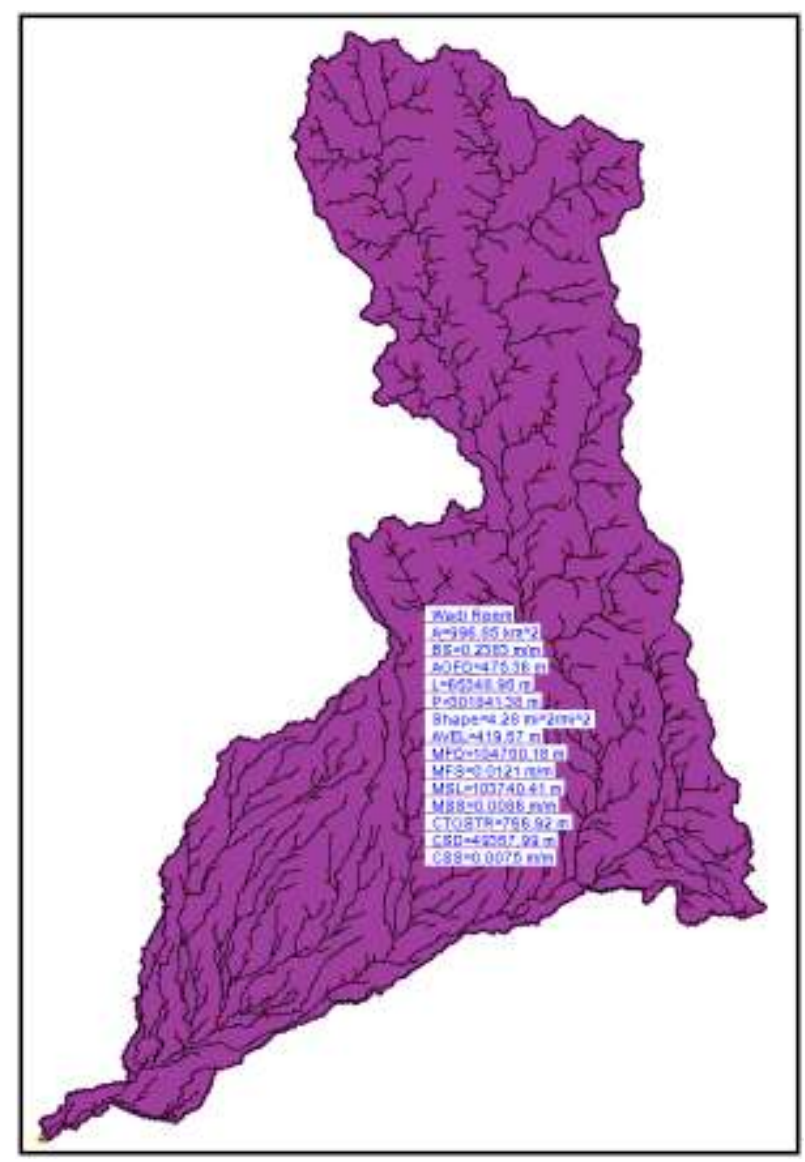

Fig. 4: Wadi Reem basin delineation extracted directly from DEM Using WMS Softwear.

Table 1: The morphological characteristics of Wadi Reem basin.

\begin{tabular}{|c|c|c|}
\hline Parameter & Units & Wadi Reem \\
\hline Basin Area (A) & $\mathrm{km}^{2}$ & 996.85 \\
\hline Basin overland Slope (BS) & $\mathrm{m} / \mathrm{m}$ & 0.238 \\
\hline Mean basin elevation (AVEL) & $\mathrm{m}$ & 419.57 \\
\hline Basin length $(\mathrm{L})$ & $\mathrm{m}$ & 65348.95 \\
\hline Basin Perimeter $(\mathrm{P})$ & $\mathrm{m}$ & 301841.38 \\
\hline Maximum Stream Lengh (MSL) & $\mathrm{m}$ & 103740.41 \\
\hline Maximum Stream Slope (MSS) (watercourse) average slope & $\mathrm{m} / \mathrm{m}$ & 0.0086 \\
\hline Basin length along main channel from outlet to upstream boundary (MFD) & $\mathrm{m}$ & 104750.18 \\
\hline Average overland flow distance (AOFD) & $\mathrm{m}$ & 475.36 \\
\hline Basin slope along main channel from outlet to upstream boundary (MFS) & $\mathrm{m} / \mathrm{m}$ & 0.012 \\
\hline Length along main channel from outlet to point opposite centroid (CSD) & $\mathrm{m}$ & 49357.99 \\
\hline Slope along main channel from outlet to point opposite centroid (CSS) & $\mathrm{m} / \mathrm{m}$ & 0.0075 \\
\hline Distance from Centroid to stream (CTOSTR) & & 766.92 \\
\hline Shape Factor & $\mathrm{m}^{\wedge} 2 /$ & 4.28 \\
\hline
\end{tabular}




\section{Mahmoud Abdelshafy and Alaa Mostafa}

\section{Geology and Land use}

Interpretation of the geological maps (GM-70C and GM-75C) (1:250,000-scale) acquired from the Saudi Geological Survey database for the study area revealed the rock types in The Wadi Reem Basin area and is shown in Figure (5).

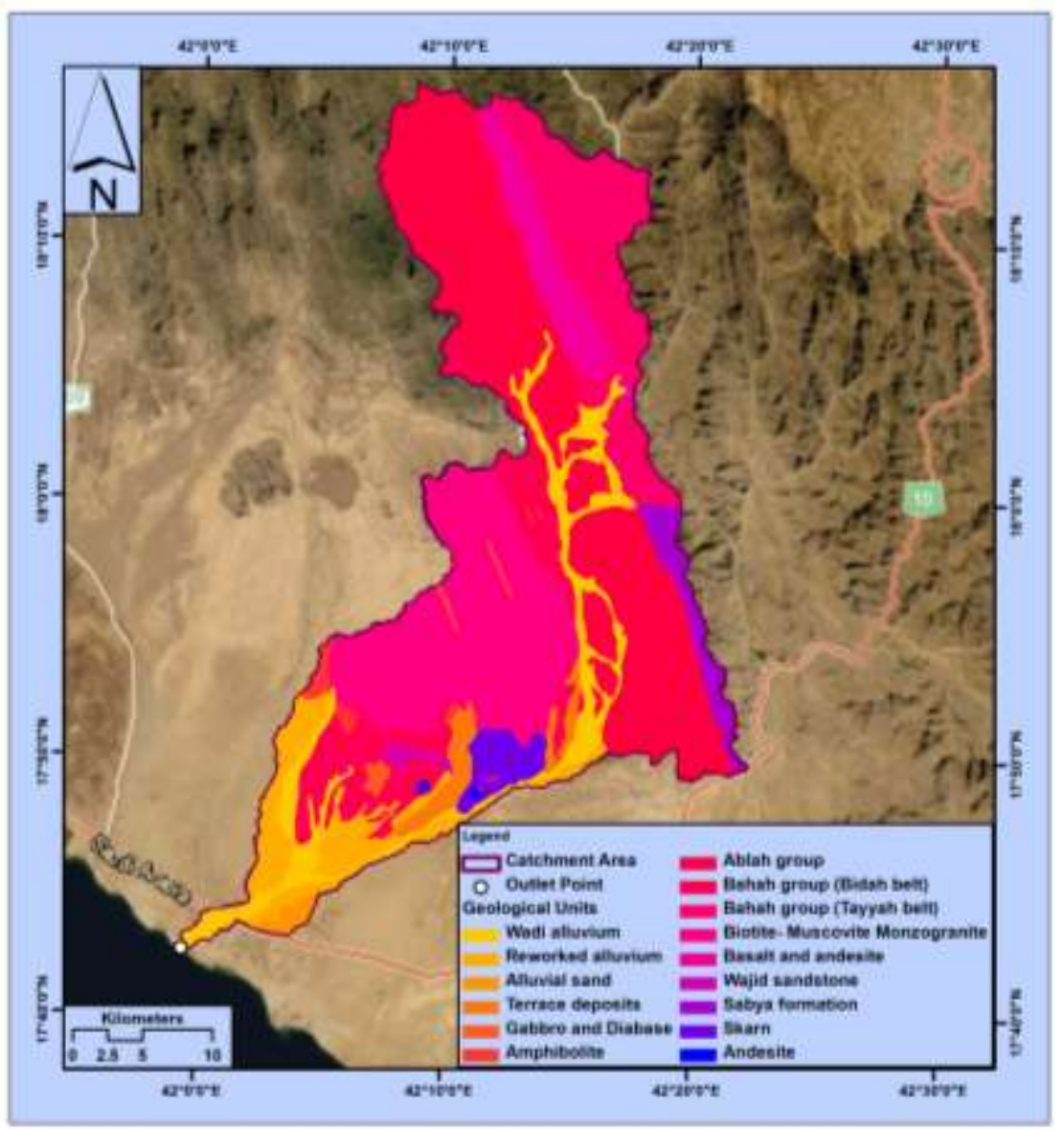

Fig. 5:Geological map of the Wadi Reem basin.

Based on field observation and the supervised classification of Setinal-2 satellite image results showed that there are seven types of land use/land cover in the studied basins, namely: Mixed forest or shrupland, Mixed cropland vegetation and shrups, Cropland and Pasture, Farmlands, Mixed Urban or Built-up Land, Rocky areas and Desert areas as shown in Figure (6). The land use classification of Wadi Reem basin is given in (Table 2) shows that $23.08 \%$ of land is used as Mixed forest or shrupland, $16.96 \%$ land is used as Mixed cropland vegetation and shrups, 3.06\% land is used as Cropland and Pasture, 8.08\% of land is used as Farmlands, 3.55\% land is used as Mixed Urban or Built-up Land, 5.08\% land is used as Rocky areas and 40.1\% land is used as Desert areas. 
Flash Flood Modeling Using HEC-RAS (2D) model on Wadi Reem in the western region, Kingdom of Saudi Arabia

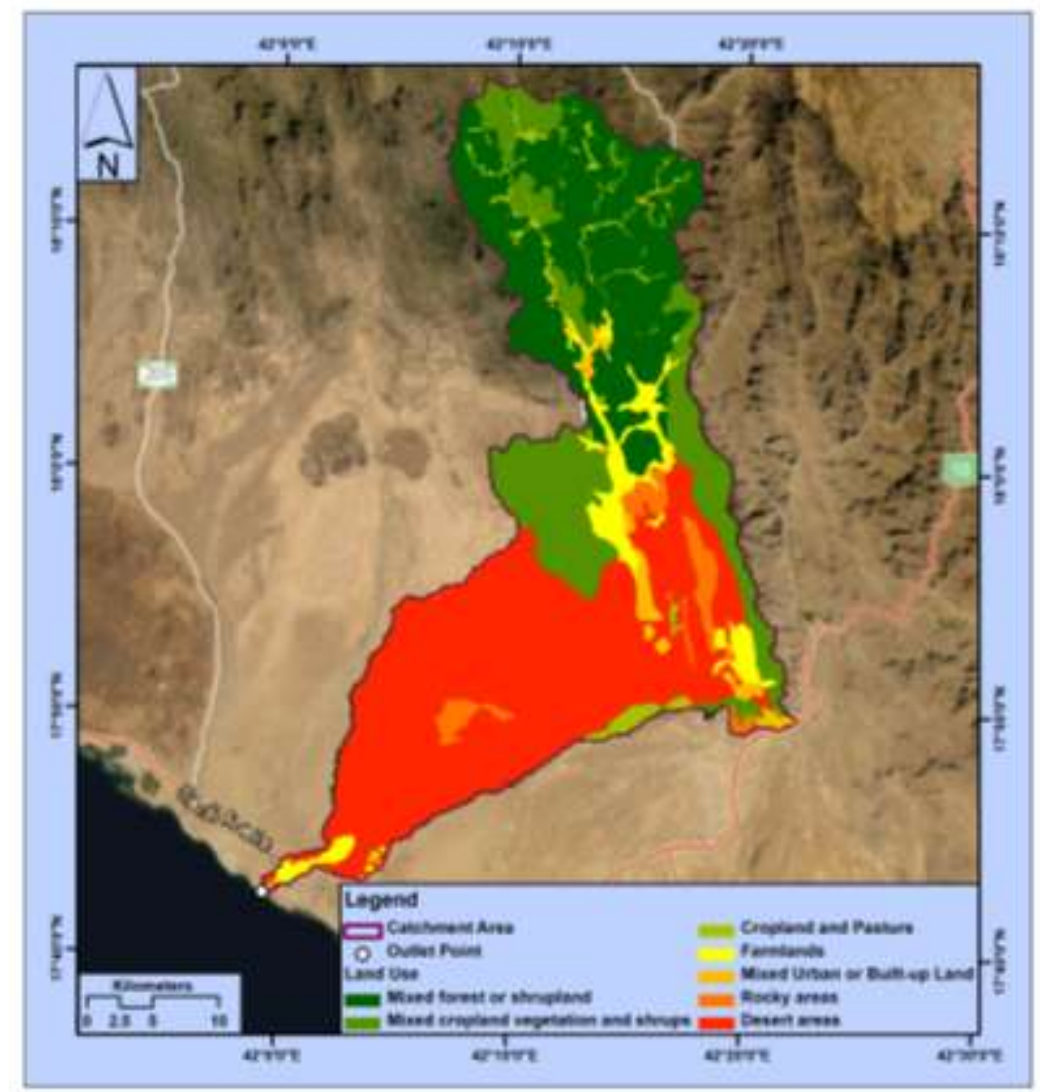

Fig. 6 :Land use map of the Wadi Reem basin.

Table (2): Classification of Land Use types and their spatial coverage in Wadi Reem basin.

\begin{tabular}{|c|c|c|}
\hline Land Use classification & Area $\mathbf{k m}^{\mathbf{2}}$ & Percentage of Area \% \\
\hline Mixed forest or shrupland & 230.13 & 23.08 \\
\hline Mixed cropland vegetation and shrups & 169.14 & 16.96 \\
\hline Cropland and Pasture & 30.54 & 3.06 \\
\hline Farmlands & 80.56 & 8.08 \\
\hline Mixed Urban or Built-up Land & 35.43 & 3.55 \\
\hline Rocky areas & 50.67 & 5.08 \\
\hline Desert areas & 400.12 & 40.1 \\
\hline SUM & 996.85 & 100 \\
\hline
\end{tabular}

\section{Hydrologic soil maps and Curve Number}

The SCS model categorizes soil types into four groups which are A, B, C and D, in accordance with their infiltration rate (Sindhu et al., 2013). CN is the curve number, a dimensionless number that range from 0-100, which is drawn from a table provided by the SCS handbook of Hydrology depending on the HSG, land use /land cover, and Antecedent moisture condition (AMC) (Songara et al., 2015; Satheeshkumar et al., 2017; Amutha and Porchelvan, 2009). The hydrologic soil groups (HSG) in the study basins included four types of Hydrologic soil Group four groups which are A, B, C and D, in accordance with their infiltration rate 


\section{Mahmoud Abdelshafy and Alaa Mostafa}

(Sindhu et al., 2013) (Fig. 7). The The calculated curve numbers for Wadi Reem basin was 72.72 as shown in Figure (8).
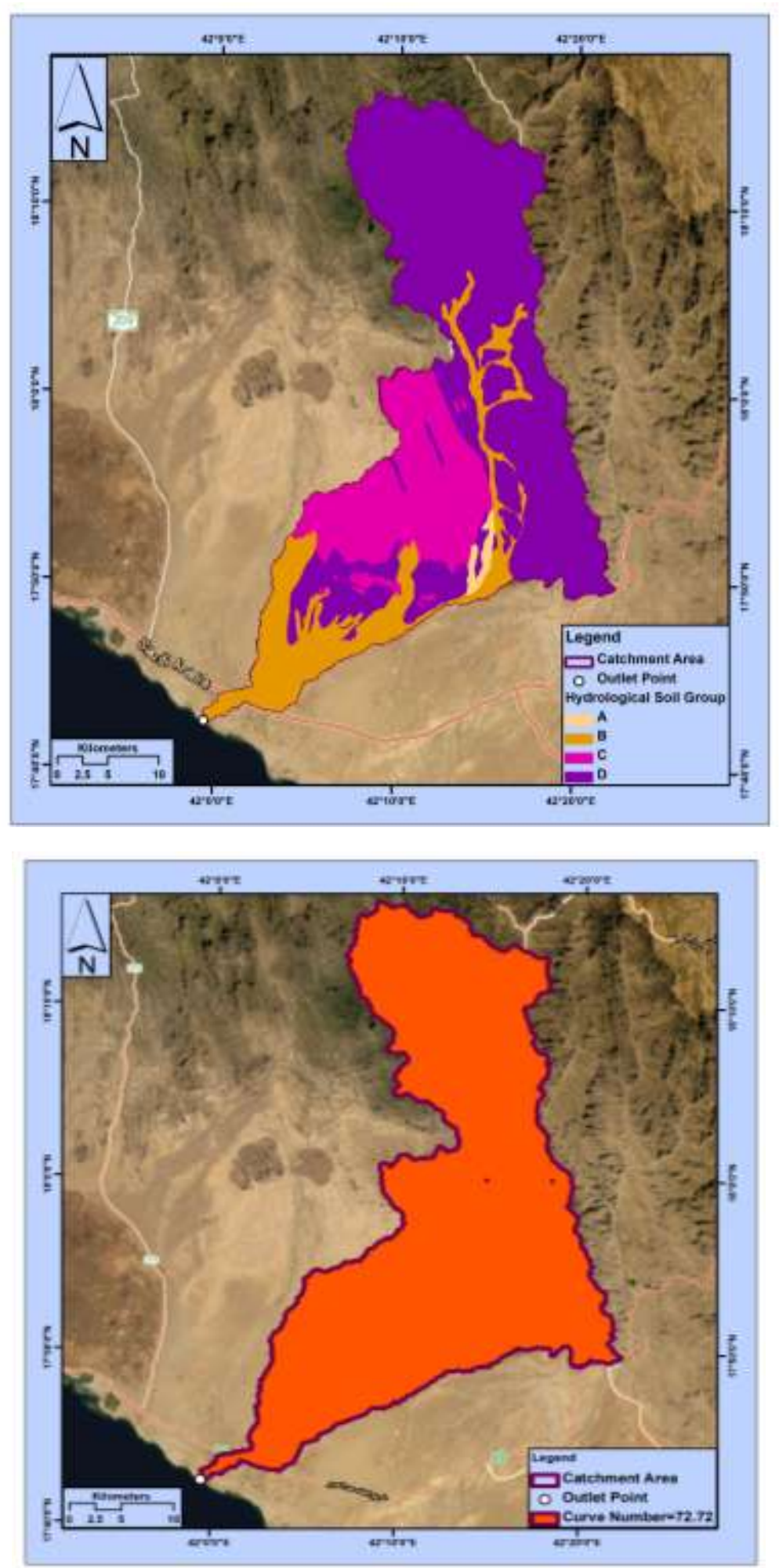

Fig . 7: hydrologic soil group's map for Wadi Reem Basin.

Fig. 8 : Curve Number map for Wadi Reem Basin. 
Flash Flood Modeling Using HEC-RAS (2D) model on Wadi Reem in the western region, Kingdom of Saudi Arabia

\section{Rainfall station data}

It was found that Wadi Reem is affected by three meteorological stations and these stations are operated by the Ministry of Water and Electricity (MOWE), according to the Thiessen polygons as shown in Figure (9). Theses rainfall station data as the following; Rajal Almaa (SA116), Alhabil (SA144) and Aldarb (SA102), The records also revealed that these stations cover a period of 44 years, 46 years and 39 years, respectively (Figs.10-12).

The depth of the rain was determined in various return periods $(5,10,25,50$, and 100 years) using the Hyfran-Plus (Hyfran, 1998) and various statistical distributions, such as normal, log-normal, Gamma, Gumbel, and log-Pearson type III, used to verify the results. It was concluded that the method (Normal) is the most suitable for Rajal Almaa (SA116), the method (Gamma) is the most suitable for Alhabil (SA144) and method (Log-Pearson type 3) is the most suitable for Aldarb (SA102) (Fig. 13) and (Table 3).

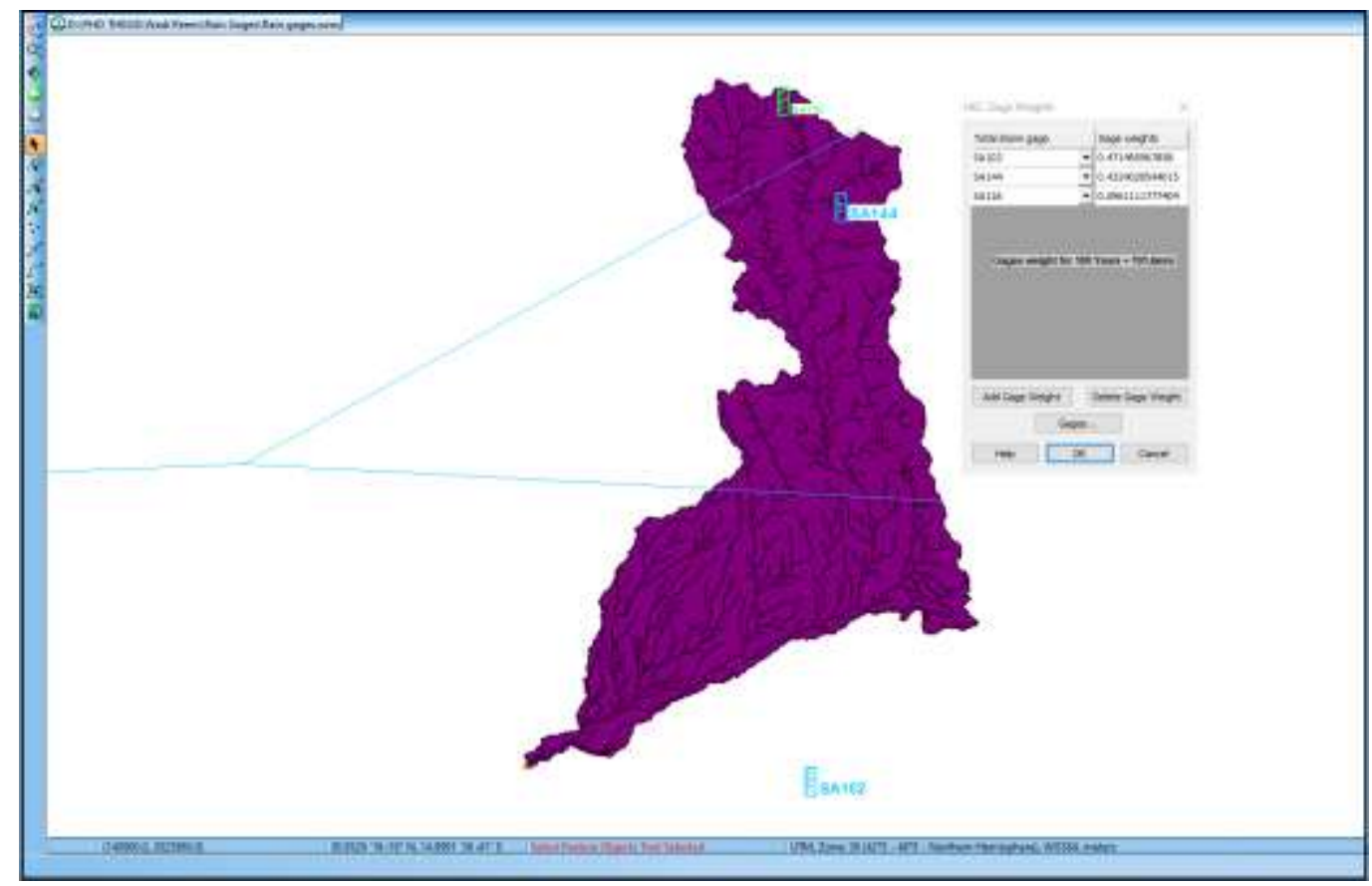

Fig. 9: Rain gages weight from all station affecing on wadi Reem basin.

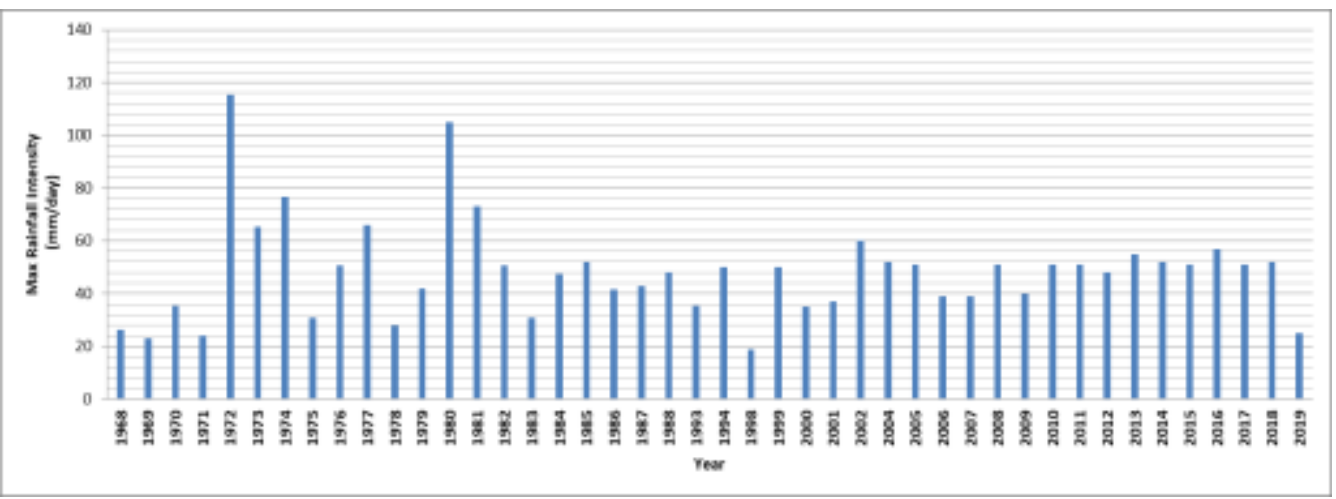

Fig. 10: Maximum annual daily rainfall of Rajal Almaa (SA116) station from 1968 to 2019. 
Mahmoud Abdelshafy and Alaa Mostafa

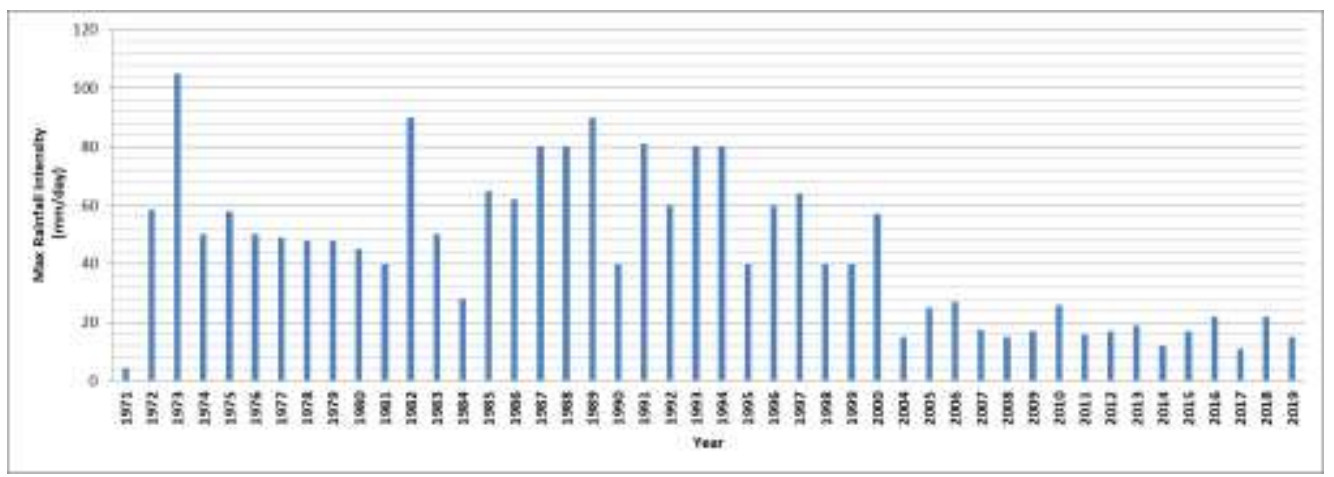

Fig. 11: Maximum annual daily rainfall of Alhabil (SA144) station from 1971 to 2019 .

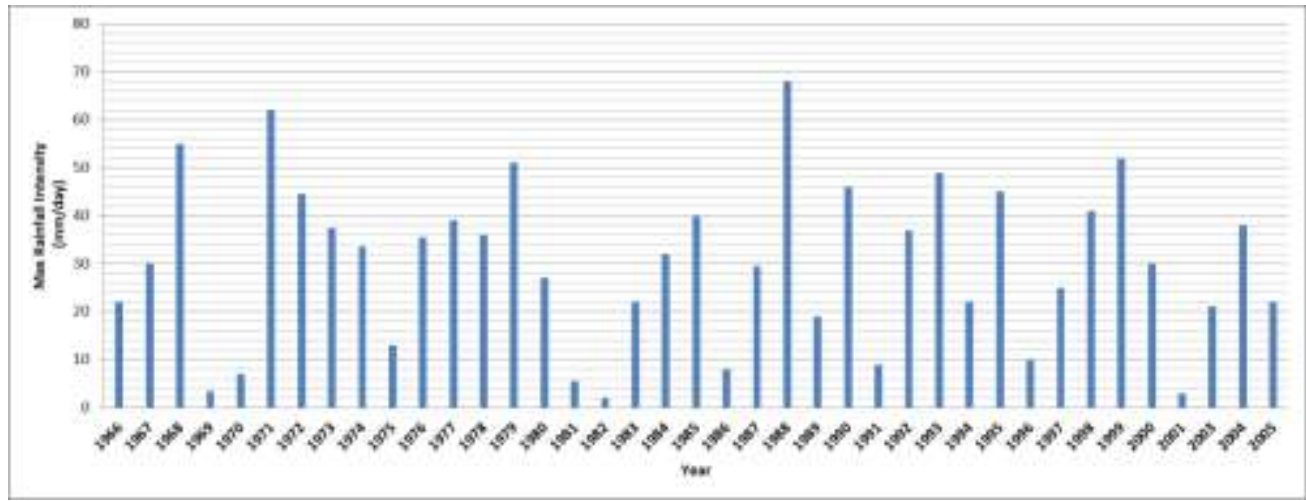

Fig. 12: Maximum annual daily rainfall of Aldarb (SA102) station from 1966 to 2005.

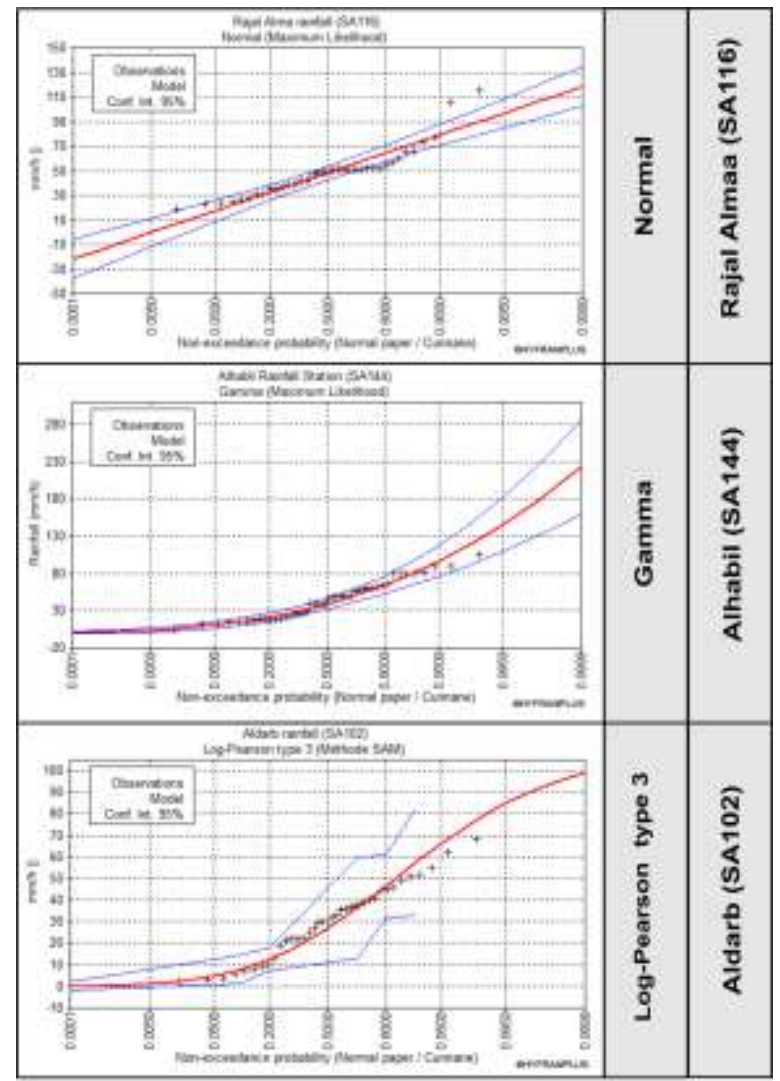

Fig. (13): Probability distribution curve of Rajal Almaa (SA116), Alhabil (SA144) and Aldarb (SA102) using Normal, Gamma and Log-Pearson type 3 distributions. 
Flash Flood Modeling Using HEC-RAS (2D) model on Wadi Reem in the western region, Kingdom of Saudi Arabia

Table (3): The results at different return periods of extreme rainfall events.

\begin{tabular}{|c|c|c|c|c|c|c|}
\hline $\begin{array}{c}\text { The series of daily } \\
\text { rainfall }\end{array}$ & $\begin{array}{c}\text { Statistical } \\
\text { distribution }\end{array}$ & $\begin{array}{c}\mathbf{5} \\
\text { years }\end{array}$ & $\begin{array}{c}\mathbf{1 0} \\
\text { years }\end{array}$ & $\begin{array}{c}\mathbf{2 5} \\
\text { years }\end{array}$ & $\begin{array}{c}\mathbf{5 0} \\
\text { years }\end{array}$ & $\begin{array}{c}\mathbf{1 0 0} \\
\text { years }\end{array}$ \\
\hline $\begin{array}{c}\text { Rajal Almaa } \\
\text { (SA116) }\end{array}$ & Normal & 64.2 & 72.5 & 81.3 & 87 & 92.2 \\
\hline Alhabil (SA144) & Gamma & 64.3 & 81.2 & 102 & 117 & 132 \\
\hline Aldarb (SA102) & $\begin{array}{c}\text { Log-Pearson } \\
\text { type 3 }\end{array}$ & 46.5 & 57.5 & 68.6 & 75.2 & 80.6 \\
\hline
\end{tabular}

\section{Hydrologic Modeling}

HEC-HMS is widely used as a rainfall runoff modeling tool, and it uses separate sub models to represent each component of the runoff process, including models that compute rainfall losses, runoff generation, base flow, and channel routing (Du et al., 2012).

After the completion of the basin model with WMS, the model was exported into HECHMS project file as shown in Figure (14); this figure shows the schematic representation of the basin model in HEC-HMS contains the hydrologic elements. After steps of the calibration and validation, we can have the runoff generated by the model after creating simulation run and view the results as $740.1 \mathrm{~m}^{3} / \mathrm{s}$ for 100 Year return period as shown in Figure (15).

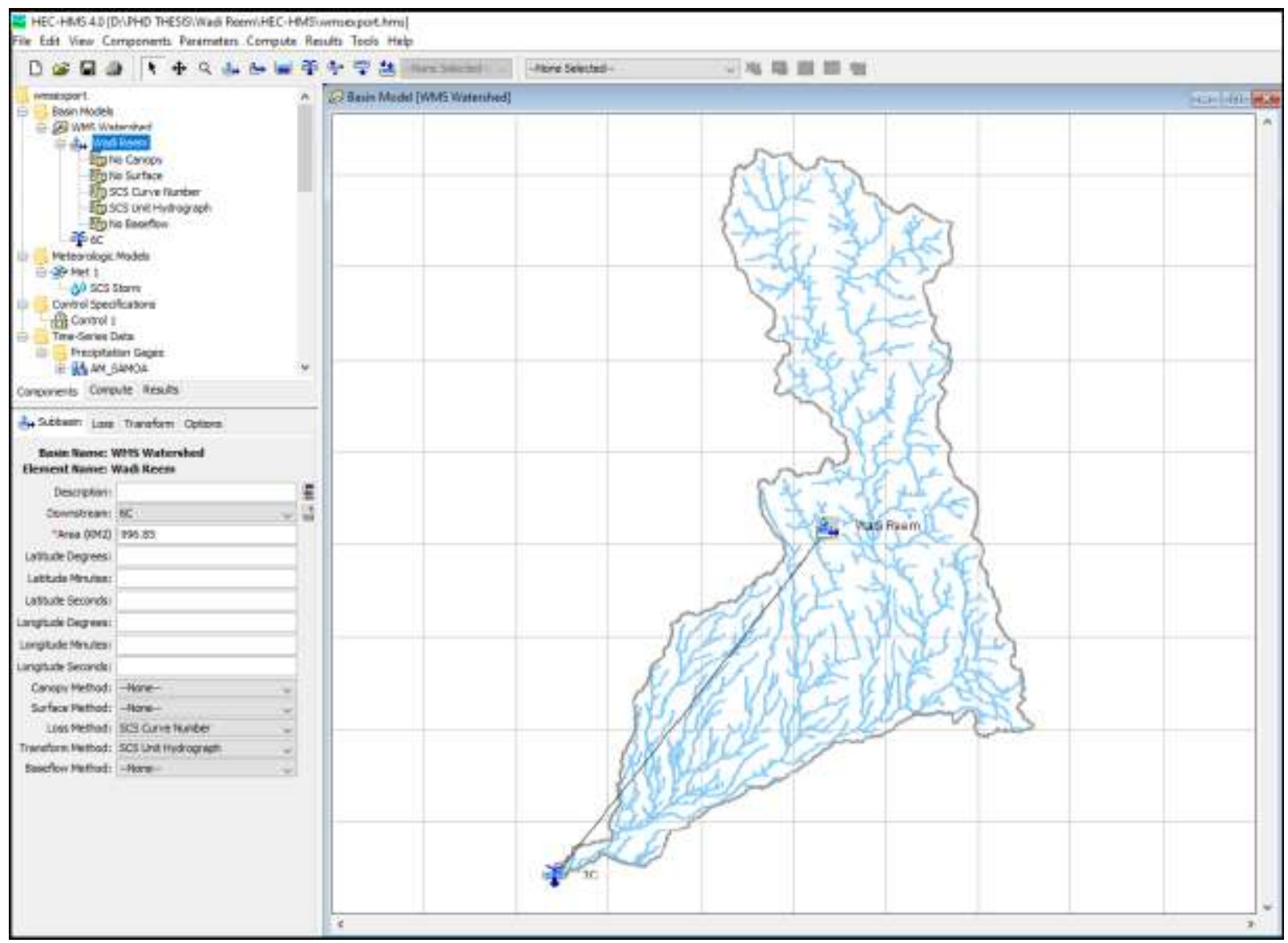

Fig. 14:schematic representation of the basin model of Reem in HEC-HMS. 
Mahmoud Abdelshafy and Alaa Mostafa

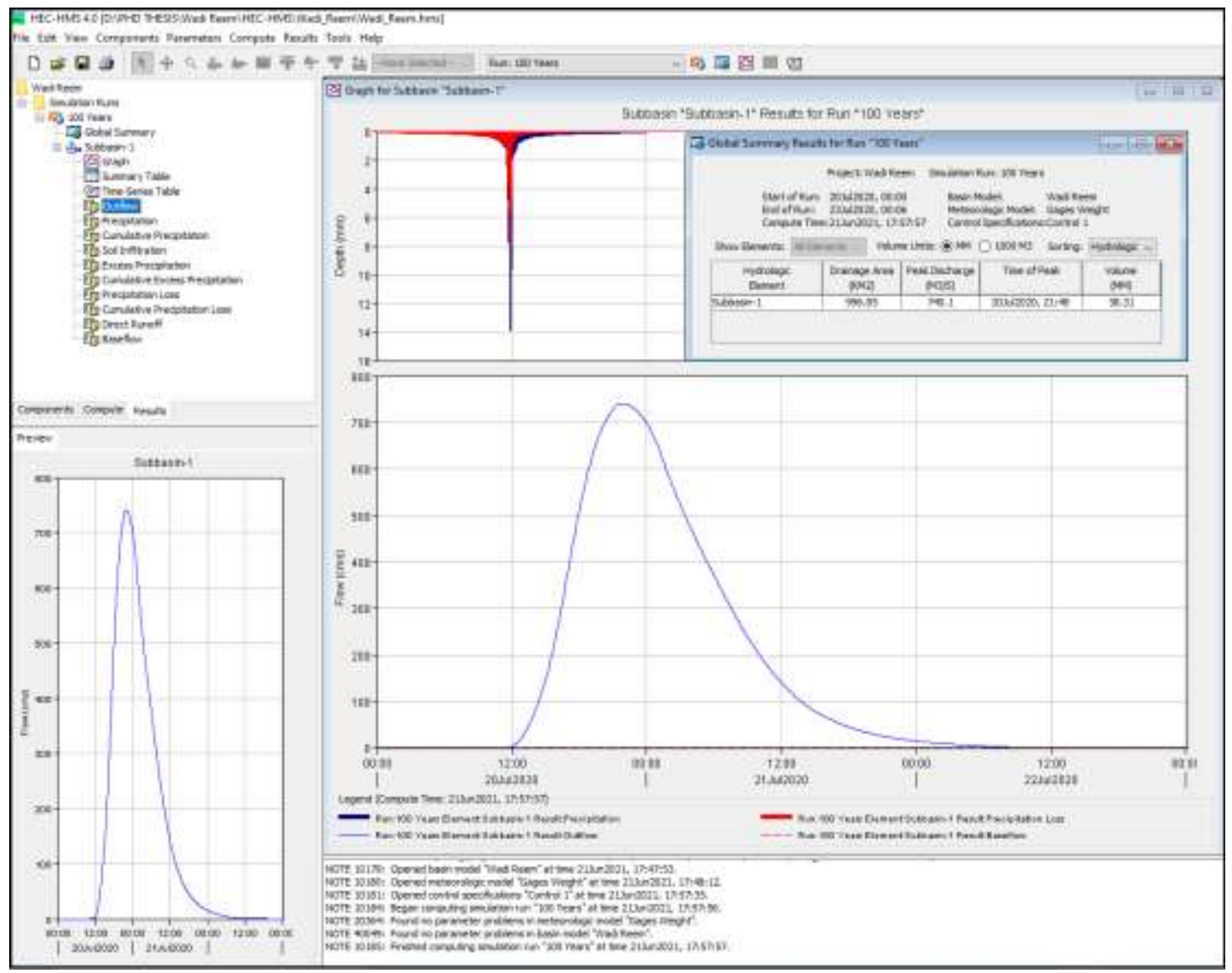

Fig. 15: Outlet Hydrograph created by HEC-HMS for 100-year Return period

\section{Hydraulic Modeling using 2D HEC-RAS Model}

The most important parameters for the HEC-RAS hydraulic model are geometric and flow data. The geometric data have been developed by drawing the stream of Wadi Reem system schematically with flow direction. This was done by using the button of river reach of the HECRAS, the methods explain in details in software manual (U.S. Army Corp of Engineers, 2010).

\section{Flood Depth}

The maximum flood depth maps were generated by the $2 \mathrm{D}$ model by taking into consideration the maximum depth for each mesh cell. It is concluded that water levels inside the existing natural channel inundated and flooded over this channel and the existing natural channel did not drainage all the water out site the built up and residential area from the north and these area may be affected by flood as shown in Figure (16). 
Flash Flood Modeling Using HEC-RAS (2D) model on Wadi Reem in the western region, Kingdom of Saudi Arabia

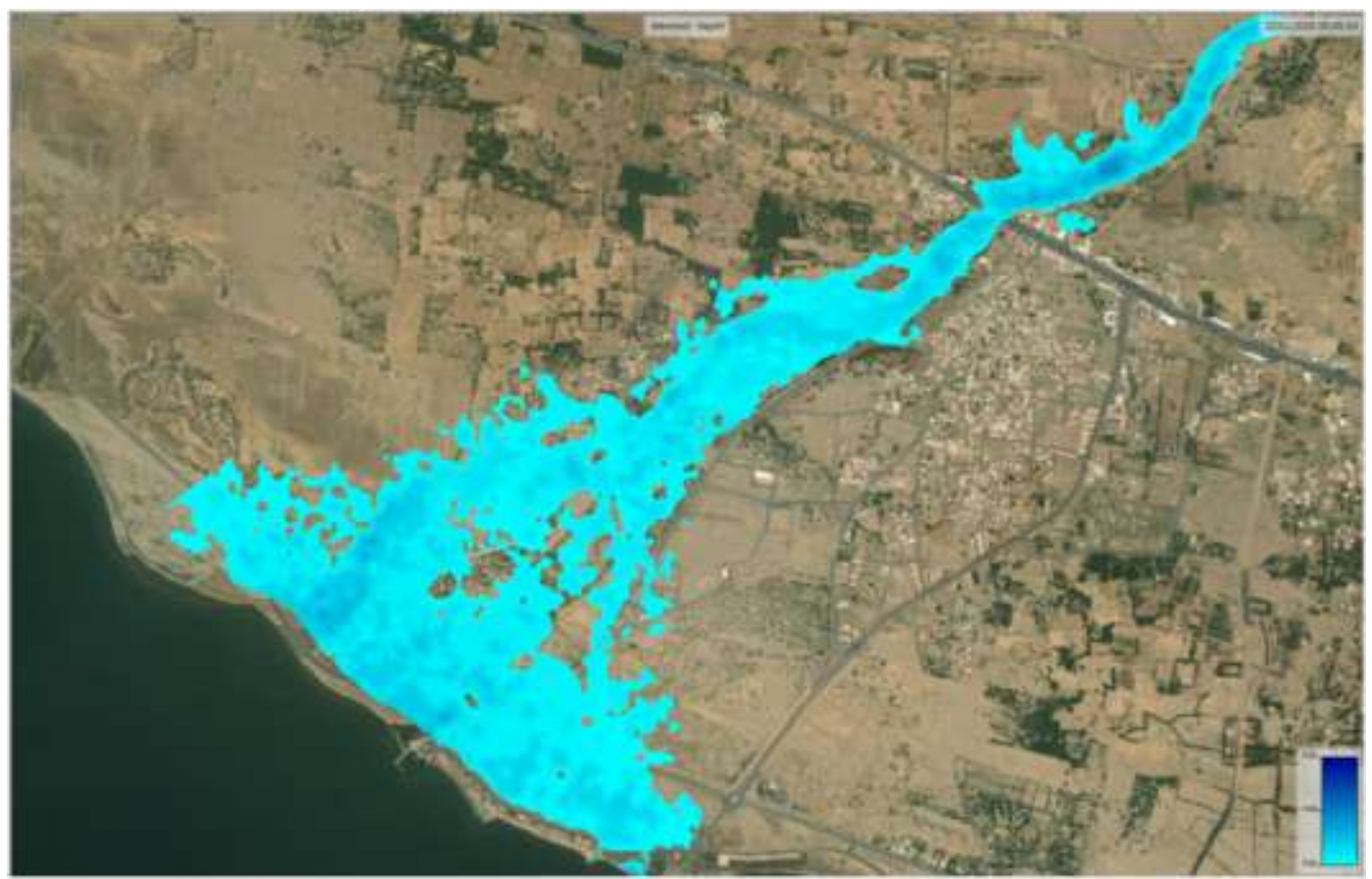

Fig. 16: Flood waters depth and flooded areas simulated by HEC-RAS2D model

\section{Flood Velocity} for 100-year of Reem.

Another important result of the $2 \mathrm{D}$ modeling process is flood velocity. This is computed by recording the maximum velocity for each cell in the computational mesh Figure (17). From this map the buildings are potentially affected by the $0.5-1 \mathrm{~m} / \mathrm{s}$ flood velocity which covers most of the flood area.

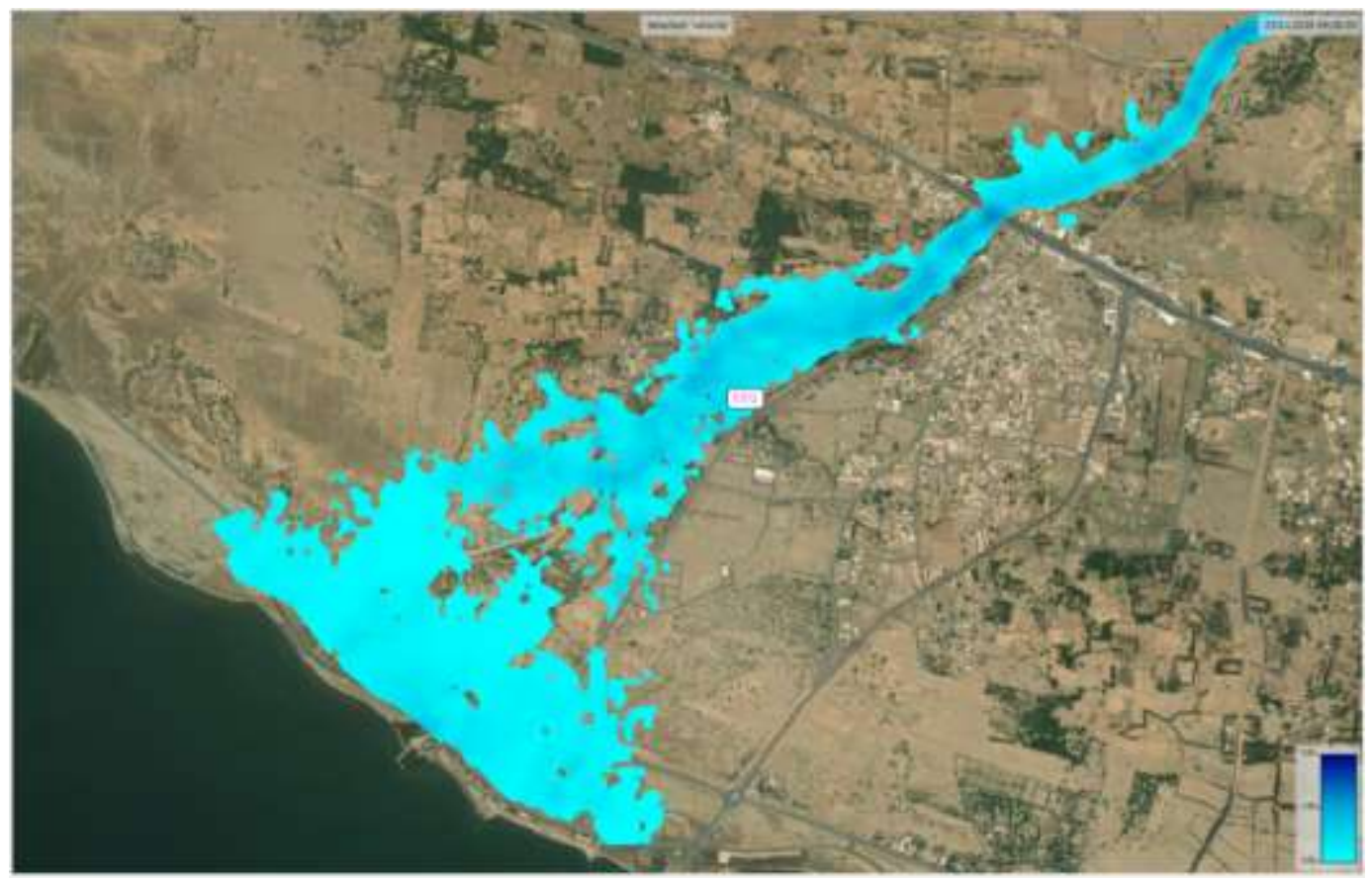




\section{Mahmoud Abdelshafy and Alaa Mostafa}

Fig. 17: Flood velocityderived from HEC-RAS 2D model for 100-year of Wadi Reem.

\section{Flood Hazard Assessment}

The flood velocity was not taken in this basin because it is below the limit. To generate the flood hazard categories, the water depth for each flood extent was classified according to the Japanese criteria of the Ministry of Land Infrastructure and Transport and the flood hazard map is shown in Figure (18).it in noticed that the high risk areas are shown in orange color and dark Blue, these regions are closer to the wadi bed. They are dangerous during floods as the water level can reach up to $4 \mathrm{~m}$. They mainly occupy the congested areas near the roads.

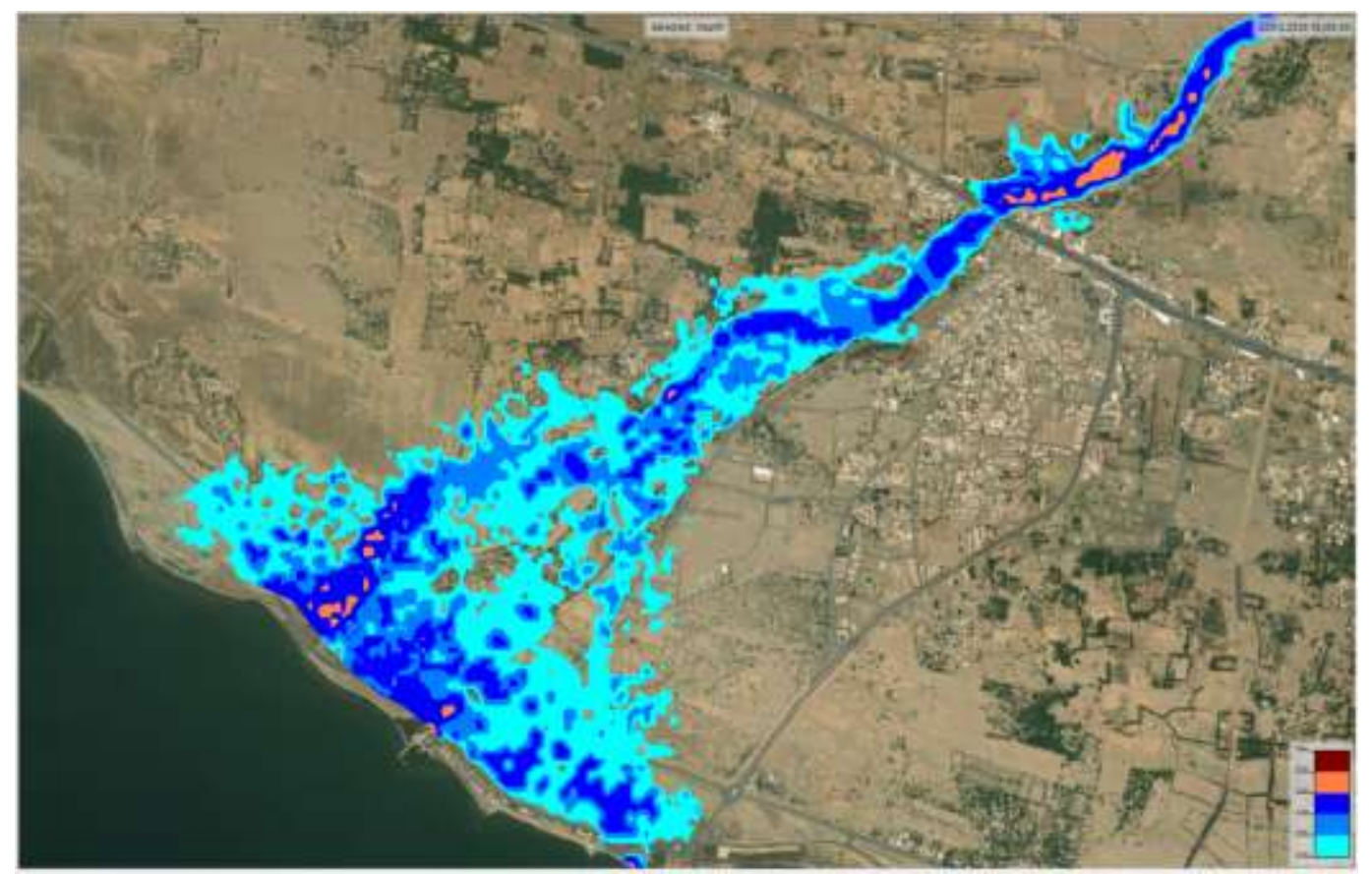

Fig - (18):Flood Hazard map of Wadi Reem based on flood depth classification according to the

MLIT derived from HEC-RAS 2D modelling.

\section{Conclusion}

The study concludes the following; the watershed of Wadi Reem and its stream delineation process were carried out with the aid of Watershed Modeling System (WMS) software. In the present study, the $\mathrm{CN}$ values found to be 72.72; Hydrologic modeling was carried out by HECHMS program that simulated rainfall-runoff process using curve number model. The HEC-HMS model was selected because it can investigate the applicability of hydrologic modeling in arid and semi-arid regions, in order to simulate rainfall-runoff through the employing of HEC-HMS model using Soil Conservation Services, Curve Number and SCS Unit Hydrograph. For 100-year return period, hydrograph results indicate that; the hydrograph volume is about 38193654 cubic meters with a peak discharge of about $740.1 \mathrm{~m} 3 / \mathrm{s}$ for Wadi Reem Basin.

This study discusses the implementation of 2D model that shows the flood water depth, spread, and velocity based on the hydraulic modeling of the HEC-RAS program for urban developing areas. The study also provides 2D model of the flood water inflow spread, velocity, 


\section{Flash Flood Modeling Using HEC-RAS (2D) model on Wadi Reem in the western region, Kingdom of Saudi Arabia}

and depth, as these characteristics are not available in the one-dimensional flood water inflow model.

The results of HE-RAS 2D Model indicated that; the main channel of Wadi Reem basin has not the capacity to carry the 100-year return period peak flood Hydrograph and the flood inundated in these wadis with different depths and velocities.

\section{REFERENCES}

Aaron, C. and Venkatesh, M. (2009). Effect of topographic data, geometric configuration and modeling approach on flood inundation mapping. J. Hydrology, 377: 131-142.

Abdel Rahman, A.A. (2006). Hydrogeological and geophysical assessment of the reclaimed areas in Sohag, Nile Valley, Egypt. Ph.D.Thesis, Geol. Dept., Fac. Sci., Ain Shams University, Cairo, Egypt.

Abdullah, M.A. and Al-Mazroui, M. (1998). Climatological study of the southwestern region of Saudi Arabia. I. Rainfall analysis. Climate Res., 9: 213-223.

Aghazadeh, N. and Mogaddam, A.A. (2010). Assessment of groundwater quality and its suitability for drinking and agricultural uses in the Oshnavieh area, Northwest of Iran. J. Environ. Protection, 1: 30-40.

Aljerash, M.A. (1985). Climatic subdivisions in Saudi Arabia: an application of principal component analysis. Int. J. Climatol. 5: 307-323.

Ally, W.M.; Dawdy, D.R. and Schaake, J.C. (1980). Parametric deterministic urban watershed model. J. Hydraul. Div., ASCE 106(5): 679-690.

Almazroui, M. (1998). Climatological study over the southwestern region of the Kingdom of Saudi Arabia with special reference to rainfall distribution. M.Sc Thesis, Department of Meteorology, Faculty of Meteorology, Environment and Arid Land Agriculture, King Abdulaziz University, Jeddah, Saudi Arabia.

Altaher, A.A. (1994). Drought and human adjustment in Saudi Arabia. Geol. J., 33: 411-422.

Amutha, R. and Porchelvan, P. (2009). Estimation of surface runoff in Malattar sub-watershed using SCS-CN method. J. Indian Society of Remote Sensing, 37(2): 291-304.

Baoyin, H. and Hailin, Z. (2009). GIS-based risk evaluation for regional disaster. J. Environ. Technol. and Engin., 2(3): 87-91.

Du, J. ; Qian, L. et al. (2012). Assessing the effects of urbanization on annual runoff and flood events using an integrated hydrological modeling system for Qinhuai River basin, China. J. Hydrology, 464:127-139. At: http://folk.uio.no/chongyux/papers_SCI/jhydrol_30.pdf>

Feldman, A.D. (1995). HEC-1 flood hydrograph package, Comput. Models Watershed Hydrol., 119-150.

Hyfran, M. (1998). Developed by INRS-Eau with Collaboration of Hydro-Québec Hydraulic Service (Department Hydrology). in the Framework of Hydro-Québec/CRSNG Statistical Hydrology Chair Located at INRS-Eau. At: http://www.wrpllc.com/books/hyfran.html.

Hydrologic Engineering Centre (2008): HEC-RAS, River Analysis System Hydraulic Reference Manual.

Hydrologic Engineering Center (2016): HEC-HEC-RAS 5.0 Hydraulic Reference Manual.

Köppen, W. (1936). Das Geographisca System der Klimate. Handbuch der Klimatologie: In: Köppen, W., Geiger, G. (Eds.), C. Gebr. Borntraeger, Vol. 1, pp. 1-44.

McColl, C. and Aggett, G. (2007). Land-use forecasting and hydrologic model integration for improved land-use decision support. J. Environ. Mmanag., 84(4): 494-512. At:http:// 


\section{Mahmoud Abdelshafy and Alaa Mostafa}

www.sciencedirect.com/ science/article/pii/ S0301479706001915

Ouyang, N.L.; Lu, S.L.; Wu, B.F.; Zhu, J.J. and Wang, H. (2011). Wetland restoration suitability evaluation at the watershed scale- A case study in upstream of the Yongdinghe River. Procedia Environmental Science, 10: 1926-1932.

Satheeshkumar, S.; Venkateswaran, S. and Kannan, R. (2017). Rainfall-runoff estimation using SCS-CN and GIS approach in the Pappiredipatti watershed of the Vaniyar sub basin, South India. Modeling Earth Systems and Environment, 3(1): 24.

Sindhu, D.; Shivakumar, B.L. and Ravikumar, A.S. (2013). Estimation of Surface Runoff in Nallur Amanikere Watershed Using Scs-Cn Method, 404-409.

Singh, L.K.; Jha, M.K., and Chowdary, V.M. (2017). Multi- criteria analysis and GIS modeling for identifying prospective water harvesting and artificial recharge sites for sustainable water supply. J. Cleaner Production, 142: 1436-1456.

Songara, J. C.; Joshipura, H.T.K.N.M. and Prakash, I. (2015). Estimation of Surface Runoff of Machhu Dam III Chatchment Area, Morbi, Gujarat, India, using Curve Number Method and GIS. International Journal of Advance Engineering and Research Development (IJAERD)3(03): 2038-2043.

Strahler, A.N. (1964). Quantitative geomorphology of drainage basins and channel networks. Handbook of Applied Hydrology. McGraw HillBook Company, New York, 411.

Subyani, A.; Qari, M.H.; Matsah, M.E.; Al-Modayan, A.A. and Al-Ahmadi, F.S. (2009). Utilizing remote sensing and GIS techniques to evaluate and reduce hydrological and environmental hazards in some wadis, western Saudi Arabia. King Abdulaziz City for Sciences and Technology, Project No. APR 25/101.

Teng, J.; Jakeman, A.J.; Vaze, J.; Croke, B.F.W.; Dutta, D.; Kim, S. (2017). Flood inundation modelling: A review of methods, recent advances and uncertainty analysis. Environ. Model. Softw., 90: 201-216.

U.S. Army Corp of Engineers, (2010). River analysis system, "Version 4.1, Hydrology Engineering Center, Davis CA 95616.

Viji, R.; Prasanna, P.R. and Ilangovan, R. (2015). Modified SCS-CN and Green-Ampt Methods in Surface Runoff Modelling for the Kundahpallam Watershed, Nilgiris, Western Ghats, India. Aquatic Procedia, 4: 677-684.

WHO (2020). World Health Organisation - Flood [WWW Document]. URL (accessed 4.29.20).

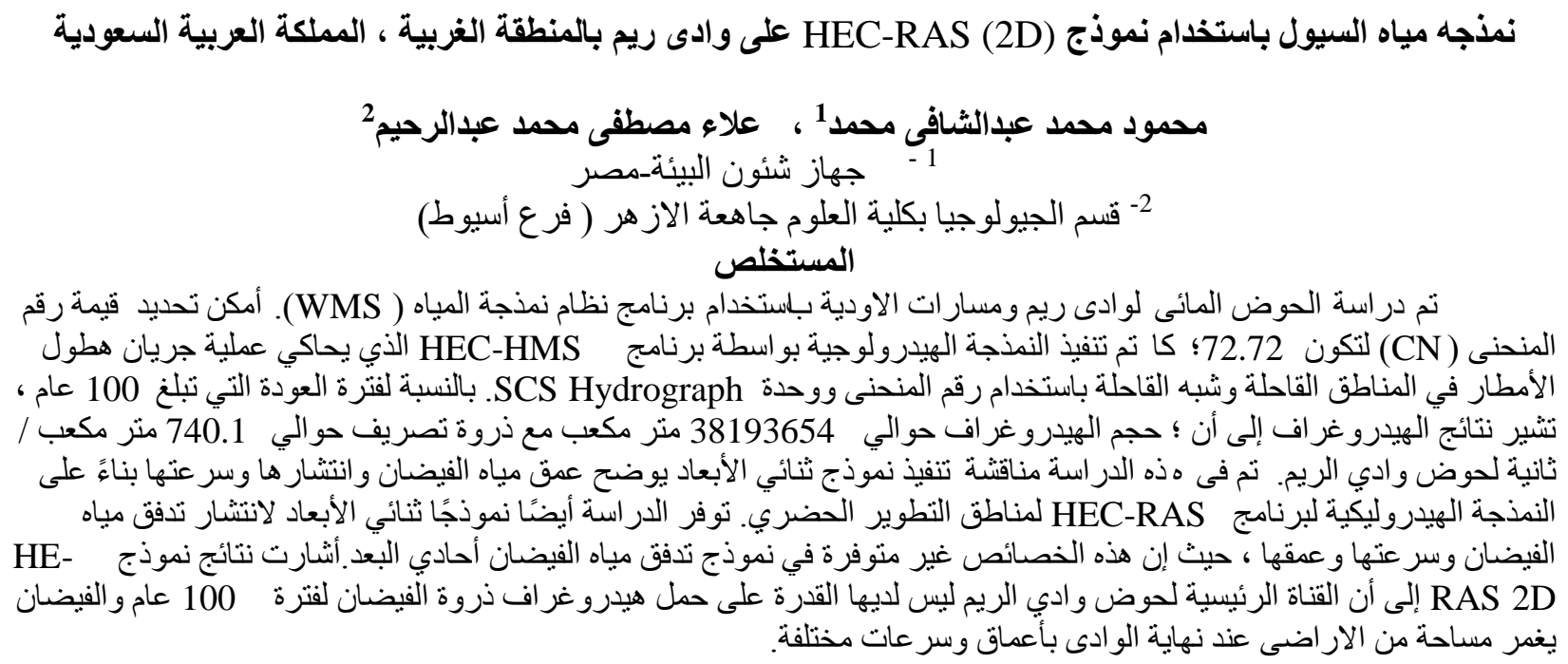

